\title{
EARTHQUAKE RISK REDUCTION ACTIONS FOR NEW ZEALAND
}

\author{
David J. Dowrick ${ }^{1}$
}

\begin{abstract}
This paper discusses what we already do and what extra should be done to reduce earthquake risk in New Zealand. Some of the needed actions have been learned from the consequences, good as well as bad, of earthquakes that have occurred both in New Zealand and in other parts of the world. A list of 26 weaknesses are identified in New Zealand's systems of earthquake risk reduction. Remedial actions to overcome these weaknesses in a balanced way involve at least nine parties. Fifteen of the weaknesses have five or more parties who could or should take some remedial action over them. Engineers have technical actions to address 20 of the weaknesses, while earthquake-related professions have an advocacy role to play in all of them. The potential exists for reducing earthquake losses by about an order of magnitude, i.e. worth billions of dollars and thousands of casualties in future earthquakes.
\end{abstract}

\section{I.0 INTRODUCTION}

The recent earthquake disasters in Turkey, Taiwan and India have their lessons for other parts of the world, including New Zealand. The big simple observation about Turkey, Taiwan and India is that the terrible losses of life, injuries, losses of jobs, and so on, could so easily have been greatly reduced if even modest use had been made of the more readily implementable knowledge that has been available in the past few decades. These countries sadly had gaps in their systems which could easily have been made good.

All seismically active regions in the world have a need to reduce their earthquake risks, even the most advanced countries. For example, in the USA the EERI (2002) is proactively trying to involve all its members in combating the growth of earthquake vulnerability of the built environment. In New Zealand, as elsewhere, we need the help of many vocations to not only arrest vulnerability but also to reduce earthquake risk.

Obviously all societies and their systems of dealing with perils are imperfect. Hence even the countries most advanced in earthquake resistance science and technology have gaps in their defences, such as was illustrated by the severe effects of the earthquake that hit the Kobe area of Japan in 1995, and the many buildings which were defective in the Northridge earthquake which hit California in 1994. So we in New Zealand need to examine what gaps exist in our mainly good systems of earthquake risk reduction, and need to fill the gaps in appropriate ways. There are such gaps in New Zealand. So there are some unnecessary disasters waiting to happen. We will discuss them below.

First, however, we should recognise the good parts of our system, the strengths that we have to build on in order to reduce earthquake risk to people, property and prosperity in our country

\subsection{NEW ZEALAND'S EARTHQUAKE RISK REDUCTION STRENGTHS}

New Zealand has sufficient strengths in the arena of earthquake risk reduction to provide a firm and clear basis for improvements to be made in the future. When the main strengths are labelled generically, we here able to identify 16 (there may be more). The strengths are listed in Table 1, where they have been divided into three groups of five or six each, designated as:

- People attributes

- Control of the built environment

- Societal attributes

People attributes comprise all the main skills required, i.e. research, design, construction, enforcement, planning and management. Many of our specialists are highly regarded internationally, and have strong international links.

Control of the built environment is assisted by having good design regulations for new buildings, bridges and dams, and some existing property. In addition, reasonable supplies are available of good earthquake resistant construction materials.

Societal attributes comprise awareness and concern about earthquake risk, together with reasonable levels of poverty, corruption and financial resources, despite New Zealand not being a rich country. In addition, modern and effective systems of government, education, information technology and communications are operative, and we are fortunate to have what is one of the world's highest levels of take-up of earthquake insurance cover.

\subsection{NEW ZEALAND'S EARTHQUAKE RISK REDUCTION WEAKNESSES}

We now turn our attention to the weaknesses in our efforts to reduce earthquake risk. Perhaps surprisingly, 26 weaknesses have been identified here in a preliminary list of weaknesses of a wide range of types. The weaknesses have been initially

\footnotetext{
${ }^{1}$ Institute of Geological and Nuclear Sciences, Lower Hutt (Fellow).
} 
divided into two main categories, named strategic and tactical as listed in Tables 2(a) and 2(b), respectively. This division in some cases is somewhat arbitrary, but it helps in comprehending the considerable detail implied by the abbreviated descriptions given to the tabulated weaknesses.

\section{Table 1: List of New Zealand's strengths in earthquake} risk reduction

\section{People Attributes}

1. Competent earthquake research (engineering, geology, seismology)

2. Competent engineering and architectural design*

3. Competent construction industry*

4. Competent enforcement*

5. Competent emergency planning and management

\section{Control of the Built Environment}

6. Earthquake design regulations for new property

7. Regulations for retrofitting unreinforced masonry

8. Houses mostly timber-framed

9. Good construction materials available

10. Good progress on protection of lifelines

\section{Societal Attributes}

11. Minimal corruption

12. Above average national financial resources

13. Moderate degree of poverty

14. Strong bureaucracy, and strong education, communication and IT systems

15. Widespread earthquake insurance

16. A close-knit and co-operative society, with strong international links

Note: ${ }^{*}$ See also Table $2(\mathrm{~b})$

Consider the 11 strategic weaknesses listed in Table 2(a). The first of these is clearly strategic, noting that New Zealand has no national strategy for managed progressive reduction of earthquake risk. We need monitored goals of target risk reductions in a series of (say) five-year plans, with priorities assigned at both a national and a local level.

As well as listing weaknesses, Tables 2(a) and 2(b) attempt to list all parties who contribute to remedying each of the weaknesses. The first of these is Advocacy by earthquake professionals (engineers, geologists, seismologists, architects, economists, planners, risk managers and others), and one is Funding (rather than people). The remaining 10 entities, ranging from engineers to central government, illustrate the complexity of the workings of modern society, which by fragmentation constitutes a considerable difficulty (i.e. a weakness) as listed in Item A3. As given in Table 2(a), Architects (A), Contractors (C), Engineers (E), Central Government (G), government departments (g), Local government $(\mathrm{L})$ and planners $(\mathrm{P})$, all are needed to address this problem, in addition to the advocacy role of earthquake professionals. The complexity of the risk reduction process is highlighted by the fact that 15 of the weaknesses listed in Tables 2(a) and 2(b) have five or more parties who could or should take some remedial action over them. Some kind of permanent forum is required to maximize the outcomes of the efforts of all 11 entities, presumably under the same umbrella as the national strategy (Item A1).
The low funding of codes and standards (Item A4) and the sometimes slow uptake of research findings (Item A7) are of course linked. This is illustrated by the length of time between new editions of the New Zealand loadings standard, which since 1965 have been published on average at nine year intervals.

The lack of contingent capacity in our hospitals (Item A5) is continually being highlighted in the news media, particularly during the season of winter ailments. Even with the temporary emergency use of military field hospitals after a severely damaging earthquake, how will the already stretched hospitals cope with the 500-1000 seriously and moderately injured people needing to be hospitalized after the next Wellington fault earthquake? The hospital system will be even more stretched because of the considerable disruption that will be caused by the earthquake to the services provided by the large hospitals in the greater Wellington region. In the aftermath of the 1931 Hawke's Bay earthquake, when a military field hospital was set up in Napier, many of the more seriously injured had to be transferred to 26 hospitals and other institutions scattered over the southern half of the North Island. Fortunately the spare hospital bed capacity in the southern North Island in 1931 was adequate. It is noted that in the 1994 Northridge, California, earthquake, of the 10 hospitals affected only the one that was seismically isolated by a lead-rubber bearing system was able to continue to function.

Losses due to business interruption generally exceed those due to material damage. Business interruption modelling (Item A6) deserves more attention than it has been given to date. Business interruption is a complex phenomenon, as illustrated by the flow chart in Figure 1. Here it is seen that business interruption may cause either negative and/or positive effects on any given "business," such as would be seen if such an analysis was applied to the medical care system (say), as part of earthquake risk preparedness/management activities.

A long drawn out attempt to address the earthquake risks represented by pre-1976 brittle structures (Items A8 and B4) has yet to bear fruit (Hopkins, 2002).

In the early days of earthquake engineering the overriding consideration of earthquake resistant design was appropriately the saving of lives, with little or no explicit attempt (or capability) to reduce damage other than that which was a side-effect of collapse prevention (Item A9). Disappointingly the modern invention of eccentrically braced frames cannot yield as intended without damaging the floors (which are then problematical to repair). Nevertheless in the last 20 years or so this situation has been changing with advances in earthquakes resistant design options and widespread requirements to keep certain types of structure, such as emergency facilities or nuclear power plants, close to undamaged in powerful earthquake shaking. In addition owners of other ("normal") classes of property are increasingly concerned to limit downtime and business interruption after earthquakes. We now are approaching the situation where damage limitation could become the primary objective of design, with life safety as the automatic side effect. The recent paper on low damage structures by Mander (2001) acknowledges this trend, and is being followed up by a research programme at Canterbury 
University on reducing damage to structures.

Table 2(a): $\quad$ Part 1 of the Preliminary List of New Zealand's weaknesses in earthquake risk reduction (please notify author of any errors or omissions).

\begin{tabular}{|c|c|c|c|c|c|c|c|c|c|c|c|c|c|}
\hline \multirow{2}{*}{\multicolumn{2}{|c|}{ A: Undesirable situations - strategic }} & \multicolumn{12}{|c|}{ Remedial action by whom } \\
\hline & & $\mathbf{A}$ & $\mathbf{E}$ & $\mathrm{C}$ & $\mathbf{a}$ & I & $\mathbf{M}$ & $\mathbf{P}$ & G & $\mathbf{g}$ & $\mathrm{L}$ & $\mathbf{F}$ & 0 \\
\hline Al & $\begin{array}{l}\text { No national strategy and targets for managed } \\
\text { incremental risk reduction with time }\end{array}$ & A & $\mathrm{E}$ & & & & $\mathrm{M}$ & & $\mathrm{G}$ & $\mathrm{g}$ & $\mathrm{L}$ & & \\
\hline A2 & $\begin{array}{l}\text { Too much national vulnerability to a large } \\
\text { earthquake on the Wellington fault }\end{array}$ & A & & & & & M & & $\mathrm{G}$ & & $\mathrm{L}$ & & \\
\hline A3 & $\begin{array}{l}\text { Fragmentation of the many endeavours } \\
\text { contributing to earthquake risk reduction }\end{array}$ & A & E & $\mathrm{C}$ & a & & & $\mathrm{P}$ & $\mathrm{G}$ & g & $\mathrm{L}$ & & \\
\hline A4 & $\begin{array}{l}\text { Underfunding of production of design codes and } \\
\text { standards }\end{array}$ & A & & & & & & & $\mathrm{G}$ & g & & $F$ & \\
\hline A. 5 & $\begin{array}{l}\text { Systematic reduction of the numbers of } \\
\text { hospitals/beds nationwide }\end{array}$ & A & & & & & & $\mathrm{P}$ & G & g & & $\mathrm{F}$ & \\
\hline A6 & $\begin{array}{l}\text { Too little management/modelling of business } \\
\text { interruption losses }\end{array}$ & A & & & & I & M & $\mathrm{P}$ & $\mathrm{G}$ & $\mathrm{g}$ & $\mathrm{L}$ & & $\mathrm{O}$ \\
\hline A7 & Slow uptake of some new research findings & A & $\mathrm{E}$ & $\mathrm{C}$ & & & & $\mathrm{P}$ & $\mathrm{G}$ & g & $\mathrm{L}$ & $\mathrm{F}$ & $\mathrm{O}$ \\
\hline A8 & $\begin{array}{l}\text { As yet no official process for retrofitting of non- } \\
\text { URM earthquake risk buildings }\end{array}$ & A & $\mathrm{E}$ & & & & & & $\mathrm{G}$ & $\mathrm{g}$ & $\mathrm{L}$ & & $\mathrm{O}$ \\
\hline A9 & $\begin{array}{l}\text { Too much emphasis on life safety at the expense } \\
\text { of high damage (e.g. EBFs) }\end{array}$ & A & $\mathrm{E}$ & & & & & & & & & & $\mathrm{O}$ \\
\hline $\mathrm{Al} 10$ & $\begin{array}{l}\text { Over-design in New Zealand's lowest seismic } \\
\text { hazard regions }\end{array}$ & & E & & & & & $\mathrm{P}$ & & & $\mathrm{L}$ & & \\
\hline A 11 & $\begin{array}{l}\text { Architects who don't accommodate engineers' } \\
\text { structural form needs }\end{array}$ & A & & & $\mathrm{a}$ & & & & & & & & $\mathrm{O}$ \\
\hline
\end{tabular}

Notes: $\quad \mathrm{A}=$ Advocacy by earthquake professions; $\mathrm{a}=$ Architects $\mathrm{C}=$ Contractors $\mathrm{E}=$ Engineers; $\mathrm{F}=$ Funding needed; $\mathrm{G}=$ Central Govt; $\mathrm{g}=$ govt dept; $\mathrm{I}=$ Insurance industry; $\mathrm{L}=$ Local govt; $\mathrm{M}=$ Economists; $\mathrm{O}=$ Owners of property; $\mathrm{P}=$ Planners.

As well as damage limitation for structures, much more design attention is needed to the reduction of damage to nonstructural elements, which accounts for much of the damage in earthquakes. This is highlighted by an analysis of a new 27-storey condominium building in Los Angeles by Shipp and Johnson (1990) in which it was estimated that in a Maximum Credible Event the building would suffer structural damage of just over $\$ 1$ million compared to nonstructural damage of just under $\$ 6.7$ million, relative to a total construction cost of $\$ 42.8$ million.

The reduction in both structural and non-structural damage requires better collaboration between architects and engineers than sadly is often the case (Item A11).

Item A10, over-design in New Zealand's lowest seismic hazard zones results from the historical excessive conservatism of design loadings for northern regions of the North Island, a situation which should be resolved in the current revision of the loadings standard. This is listed as a weakness in order to illustrate the need to spend our limited national financial resources wisely, and emphasise the need for national priorities for risk reduction as discussed above for Item A 1 .

Let us now turn to the 15 tactical weaknesses listed in Table 2(b), which generally involve more technical detail than the strategic weaknesses of Table 2(a). This is illustrated by the fact that in the Actions by whom lists, Engineers (E) appear in 14 items of Table 2(b) and only six of Table 2(a). As indicated by Items B1-B4, many components of the built environment are inadequately regulated for earthquake risk purposes. The lack of mandatory regulations for earthquake protection of most built or manufactured items other than buildings is a historical situation (common worldwide), which strongly merits rectification in the interests of earthquake risk reduction. While a design standard NZS 4219 (1983) exists for building services, its inadequacies (Item B2) have been discussed by Beattie (2000). The latter reports that audits of the services "of five buildings showed that there had usually been an effort made to provide restraint for building services, but there were often overlooked components in the load path whose failure could still cause the whole system to fail".

The case of stored goods (stock) in shops, Item B3, is a curious and alarming example. Consider the way that goods are stacked in some shops, notably some supermarkets and similar retail chains (Figure 2(a)). Lethally heavy goods are stacked needlessly high overhead in the most dangerous fashion to anyone below, including two new hardware shops in Auckland and Christchurch. The fact that loose goods or contents of buildings fall to the floor in moderate or strong shaking is common knowledge, as illustrated by Figure 3 .

These situations are, in fact, a breach of the law regarding the safety of the shop employees, and it is surprising and disappointing that this practice has not been stamped out. The deaths and injuries of workers and public alike will be the responsibility of the owners and the government, if this situation is not eliminated before the next damaging earthquake. Oddly, the public has no statutory protection 
from this source of danger at present. It is comforting to see that one chain of retail shops (The Warehouse) has recently installed a system of restraining ropes on its higher shelves, as seen in Figure 2(b). Also it is noted that in Canada a draft standard for safety of racking systems has just been issued, while the manufacturers of pallet racking systems in the USA have developed design standards.

Table 2(b): $\quad$ Part 2 of the Preliminary List of New Zealand's weaknesses in earthquake risk reduction (please notify author of any errors or omissions).

\begin{tabular}{|c|c|c|c|c|c|c|c|c|c|c|c|c|c|}
\hline & \multirow[t]{2}{*}{ B: Undesirable situations - tactical } & \multicolumn{12}{|c|}{ Remedial action by whom } \\
\hline & & $\mathbf{A}$ & $\mathbf{E}$ & $\mathbf{C}$ & $\mathbf{a}$ & $\mathbf{I}$ & $\mathbf{M}$ & $\mathbf{P}$ & G & $\mathrm{g}$ & $\mathrm{L}$ & $\mathbf{F}$ & 0 \\
\hline BI & $\begin{array}{l}\text { No EQ regulations for most equipment and } \\
\text { plant }\end{array}$ & A & $\mathrm{E}$ & & & & & & $\mathrm{G}$ & $\mathrm{g}$ & & & \\
\hline B2 & $\begin{array}{l}\text { Inadequate } \mathrm{EQ} \text { regulations for building } \\
\text { services in buildings }\end{array}$ & A & $\mathrm{E}$ & & & & & & G & & $\mathrm{L}$ & & $\mathrm{O}$ \\
\hline B3 & $\begin{array}{l}\text { Inadequate } \mathrm{EQ} \text { regulations for storage of } \\
\text { stock in shops and warehouses }\end{array}$ & A & E & & & & & & G & $\mathrm{g}$ & $\mathrm{L}$ & & $\mathrm{O}$ \\
\hline B4 & $\begin{array}{l}\text { No adequate regulatory framework for } \\
\text { existing high risk concrete and steel } \\
\text { buildings }\end{array}$ & A & $\mathrm{E}$ & & & & & & G & $\mathrm{g}$ & & & \\
\hline B5 & $\begin{array}{l}\text { Weak powers and weak action for pre- } \\
\text { emptive land-use planning }(f, l, l, \mathrm{~m})^{(1)}\end{array}$ & A & & & & & & $\mathrm{P}$ & G & & $\mathrm{L}$ & & \\
\hline B6 & Buildings astride active faults & A & $E G^{(2)}$ & $\mathrm{C}$ & & I & & $\mathrm{P}$ & & $\mathrm{g}$ & $\mathrm{L}$ & & $\mathrm{O}$ \\
\hline B7 & $\begin{array}{l}\text { Modern buildings built without measures } \\
\text { for liquefiable ground }\end{array}$ & A & $\mathrm{E}$ & $\mathrm{C}$ & & & & $\mathrm{P}$ & & & $\mathrm{L}$ & & $\mathrm{O}$ \\
\hline B8 & $\begin{array}{l}\text { Buildings located too close to steep } \\
\text { unsupported slopes }\end{array}$ & A & EG & $\mathrm{C}$ & & & & $P$ & & g & $\mathrm{L}$ & & $\mathrm{O}$ \\
\hline B9 & $\begin{array}{l}\text { Inadequate } \\
\text { regulations }^{(3)}\end{array}$ enforcement of some & A & E & $\mathrm{C}$ & & I & & $\mathrm{P}$ & G & $\mathrm{g}$ & $\mathrm{L}$ & & $\mathrm{O}$ \\
\hline B 10 & $\begin{array}{l}\text { Incomplete and/or inadequate microzoning } \\
\text { maps nationwide }\end{array}$ & A & $E G$ & & & & & $\mathrm{P}$ & & & $\mathrm{L}$ & & \\
\hline B11 & $\begin{array}{l}\text { Some councils renting out or using } \\
\text { Earthquake Risk Buildings }\end{array}$ & A & E & & & I & & $\mathrm{P}$ & & & $\mathrm{L}$ & & \\
\hline $\mathrm{B} 12$ & $\begin{array}{l}\text { Are all new materials and techniques } \\
\text { adequately researched before use? (e.g. } \\
\text { "chilly bins") }\end{array}$ & A & $\mathrm{E}$ & & & I & & & & $\mathrm{g}$ & $\mathrm{L}$ & & \\
\hline B13 & $\begin{array}{l}\text { No regular checks on seismic movement } \\
\text { gaps for seismically isolated structures }\end{array}$ & A & $\mathrm{E}$ & & & I & & & & & $\mathrm{L}$ & & $\mathrm{O}$ \\
\hline B14 & Some incompetent design ${ }^{(3)}$ & A & E & $\mathrm{C}$ & a & & & & & $\mathrm{g}$ & & & $\mathrm{O}$ \\
\hline
\end{tabular}

Notes: (1) $(\mathrm{f}, l, l, \mathrm{~m})=$ faults, landslides, liquefaction, microzoning.

(2) $E G=$ Engineers + geologists. For explanation of other abbreviations A, E etc, see Table 2(a).

(3) Shortcomings in items from Table 1, see text.

In the more seismic parts of the country two types of older buildings, of unreinforced masonry (URM) and some concrete buildings (Item B4), pose a serious threat. While many brick buildings have been demolished or strengthened in some parts of the country, the process is somewhat erratic. Even in Wellington where the City Council has been a leader in this field since about 1980, many old unreinforced brick buildings are still in use, potential death traps to occupants and passers-by. A particularly puzzling case is that of the old Harbour Board Shed (Figure 4) which until recently has been Council-owned and has been leased to a shopkeeper. Why was it left unstrengthened for so long? We might also ask why long-vacated brick buildings should not be demolished forthwith. They pose a great threat to passers-by. An example is the building on the corner of Taranaki and Buckle Streets in Wellington.

The older concrete buildings that are at risk of serious earthquake damage, (Item B4), comprise mainly pre-1976 multi-storey buildings, which have beam and column frames rather than structural walls. In the past several years, much work has been done by the NZSEE and the BIA (NZNSEE, 1996; NZSEE, 2000) on studying the problems posed by such buildings, and their proposed regulations for assessing and strengthening them were submitted to the Government late in 1998. The issue of what to do about these buildings is rightly contentious, as the costs of strengthening will be considerable in many cases. A new criterion for cost-benefit assessment has been offered by Smith (2003).

Pre-emptive land-use planning does not seem to be utilised as much as it should in reducing earthquake risk from geological effects of earthquakes (Item B5). For instance (Items B7 and B9) some modern buildings have been built on liquefiable ground without having piles or ground improvement. Other cases are those of buildings being built, sometimes knowingly, on the Wellington fault (Item B6) or too close to unsupported cut slopes that are likely to fail 
during very strong earthquakes shaking (Item B8). In a study for the ACC (Spence et al., 1998), among other things, fault rupture and landslide risks were assessed. It was found that nearly 150 buildings are located astride the fault, with the potential for about 200 deaths and injured people, as well as high damage costs, in the next Wellington fault earthquake.
In a first move to help address this situation, interim guidelines for mitigating the impacts of building on or near active faults have been issued by the Ministry for the Environment, as discussed by Van Dissen et al. (2003) and King et al. (2003).

\section{NEGATIVE EFFECTS}

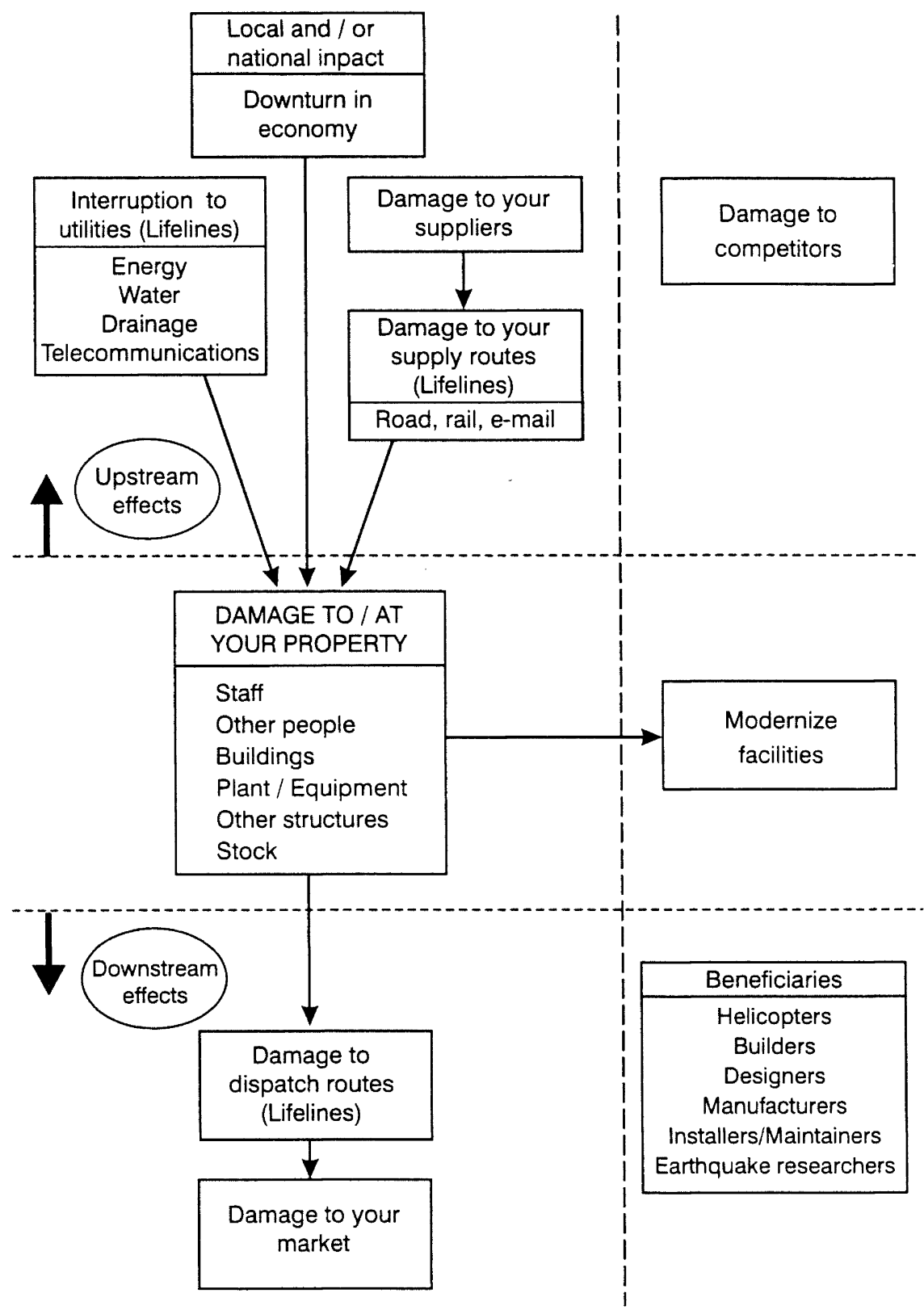

\section{OPPORTUNITIES}

Damage to 
structure, or that if a single map is used it needs to be accompanied by a set of vulnerability functions for a range of structural classes. Terrain (for landslides) needs to be accounted for, as well as geology and soils.

It is unclear whether all new building materials and techniques are being adequately researched before use (Item B 12), e.g. use of expanded polystyrene, or hay bales, in structural walls, or flax and earth proposed recently for Maori houses.

The implementation of earthquake resistance requirements in New Zealand's design standards has been shown to be reducing the earthquake vulnerability of buildings in a study of damage in the Edgecumbe earthquake (Dowrick and Rhoades, 1997). This trend is shown in Figure 5 on which are plotted the mean damage ratios, $D_{r m}$, for single storey nondomestic buildings in the intensity MM9 zone of three design standard eras, together with the 95 percent confidence intervals on the mean. For the most recent era $D_{\text {rm }}=0.032$, which is half the value of 0.064 for the earliest era, and the difference between these two values of $D_{\mathrm{rn}}$ is statistically significant at the 0.05 level. As well as this reduction in the average damage level, it is seen in Figure 5 that the incidence of heavy damage (i.e. collapse potential), as measured by the $95^{\text {th }}$ percentile of $D_{\text {rm }}$ has also reduced as the standards were revised.

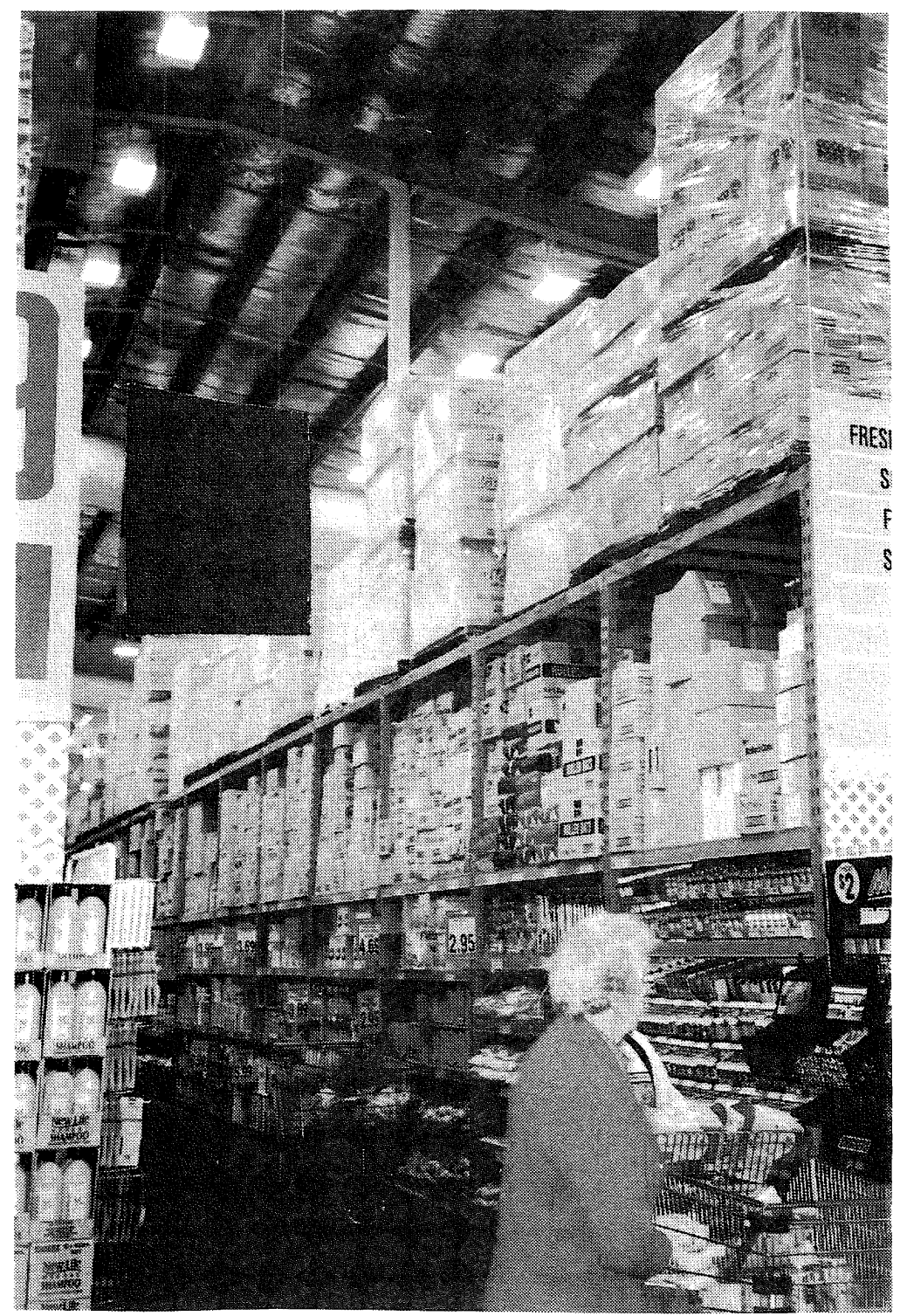

Figure 2(a): Retail shop showing dangerously stored goods.

\section{DUTY OF CARE}

An important aspect of Tables 2(a) and 2(b) is the influence of duty of care on who could be involved in remedial actions. Duty of care is the common law responsibility of a person or body to do something, such as warning others about a situation that they know to be dangerous, even if they are not involved or if there is no statutory requirement. For example building on an active fault (Item B6) is known by most people to be dangerous, so that in addition to geologists, those who could act on this danger to people and property include engineers, architects, insurers, planners, government departments, local government and the owner of the building. 
Because the duty of care is surprisingly pervasive, Tables

2(a) and 2(b) should be widely distributed to all concerned.

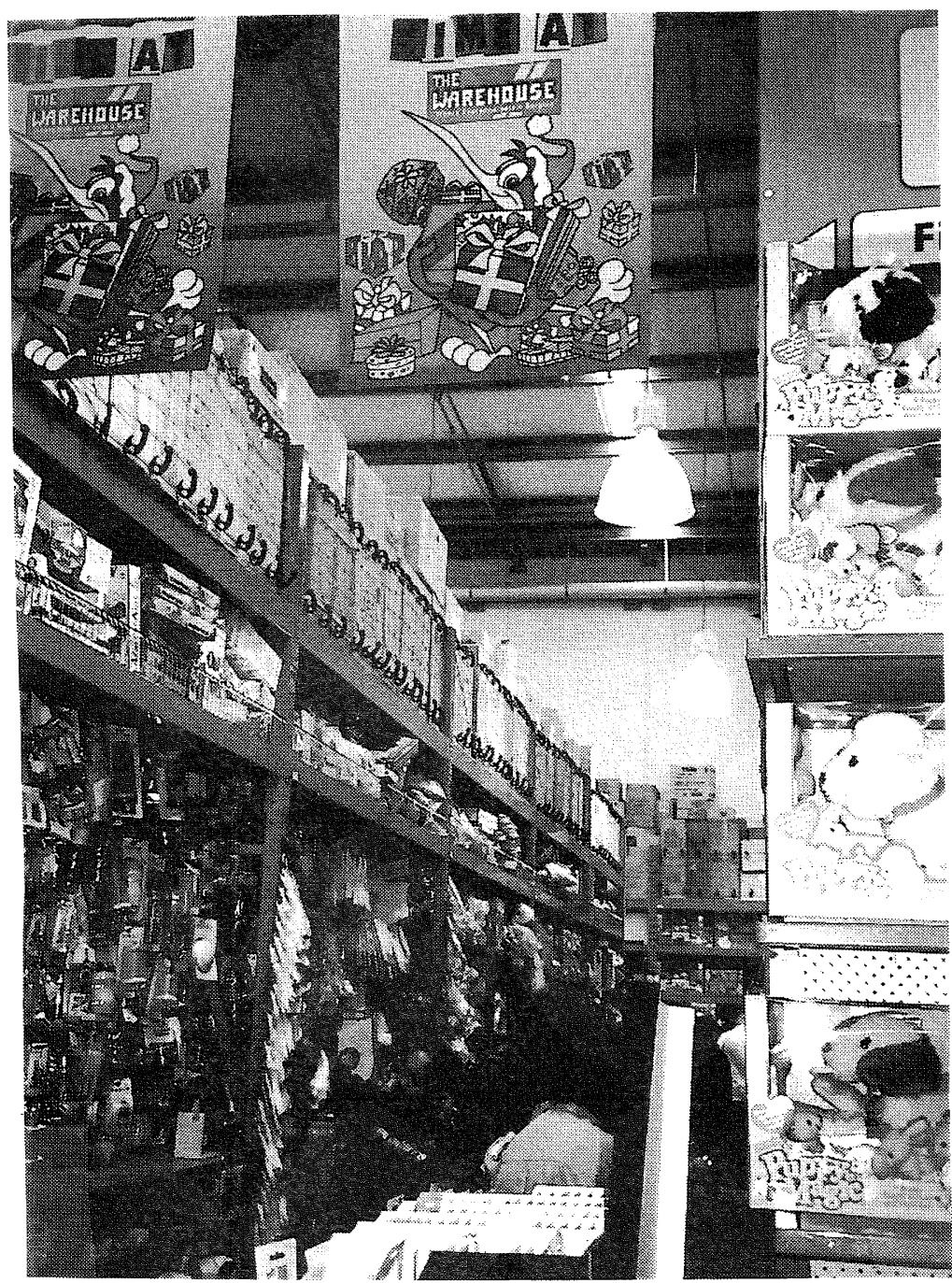

Figure 2(b): Retail shop showing a good rope system installed on higher shelves to restrain goods from falling, but some of the highest boxes are above the restraints.

Finally some reservations regarding the strengths 2,3 and 4 in Table 1 are weaknesses listed as items B14, B15 and B9 respectively in Table 2(b). Attention was focused on these design, construction and enforcement shortcomings by the hard-hitting report sent to IPENZ by Scarry (2002). This resulted in a wide-ranging and thorough review being conducted by the engineering profession (IPENZ, 2003). While the problems documented by Scarry were fortunately found not to be endemic by the IPENZ Taskforce, their report ends with seven significant recommendations, all of which are included here in Table 2.

The most important recommendation arguably is their No 3 , i.e.:

"Ongoing professional involvement. There is a need to ensure ongoing professional involvement so that the effective sign-off of structural work post-construction (including all the variations from the iterative process described above) when required is by a competent structural engineer."

\subsection{EARTHQUAKE RISK REDUCTION POTENTIAL}

The potential for earthquake risk reduction for buildings and equipment is further illustrated by Figure 6. Here are plotted the mean damage ratios, $\mathrm{D}_{\mathrm{rm}}$, over a range of intensities from Modified Mercalli V (MM5) to MM10, as found for New Zealand buildings and equipment in various earthquakes (e.g. Dowrick and Rhoades, 1997; Dowrick et al., 2001). It is seen that the lower bound $D_{n n}$ is about one thirtieth of the upper bound value over the range of damaging intensities MM7MM10. A similar range of values of $D_{r m}$ has been found for household contents and non-domestic contents (i.e. stock) by Dowrick (2003) This suggests that there is the potential for about an order of magnitude reduction in earthquake losses, if the whole built environment were to be converted to the lower bound of vulnerability. This would save billions of dollars as well as many hundreds of casualties in a Wellington fault earthquake. 


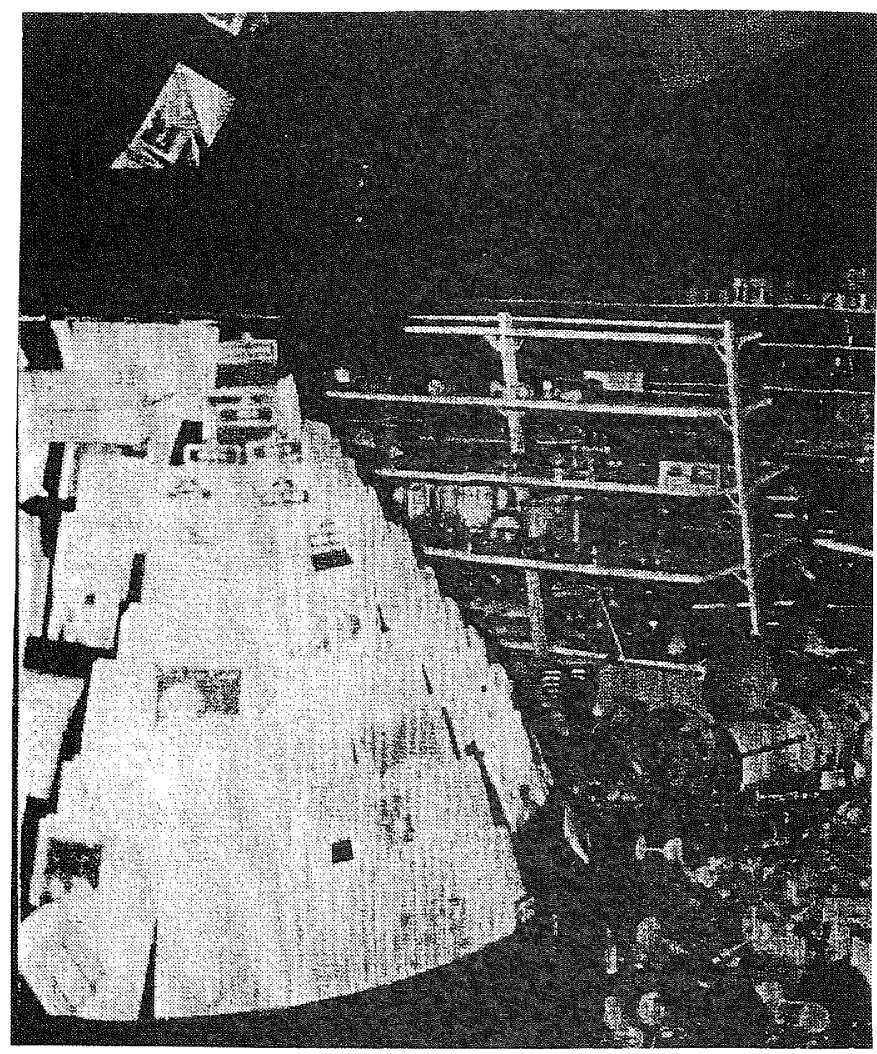

Figure 3: Unrestrained goods shaken from shelves in a shop in Edgecumbe in 1987, intensity MM9 (Photo from A. Charleson).

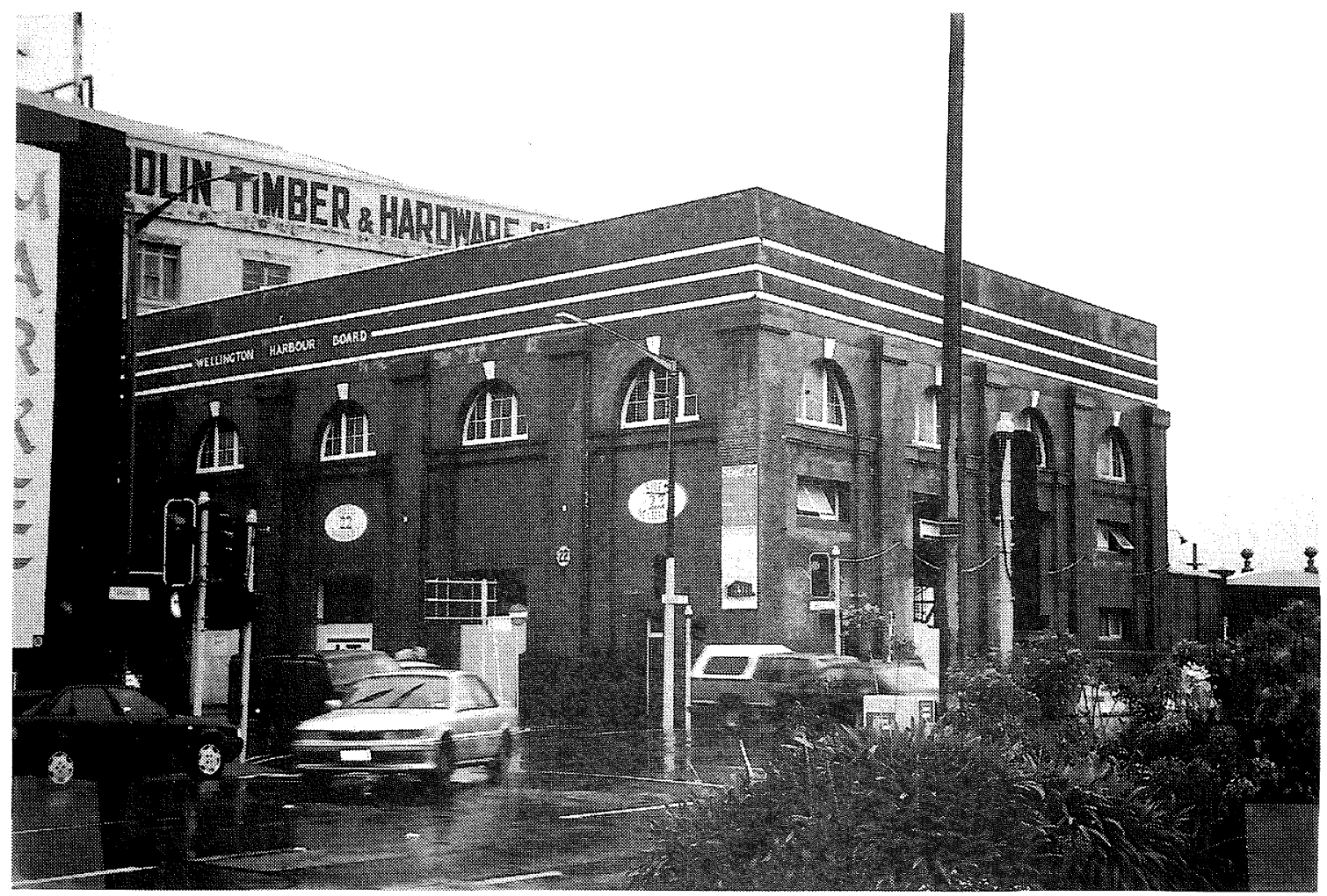

Figure 4: Publicly owned unreinforced masonry building in Wellington being retrofitted in 2002, having been rented to a retailer until late 1991. 


\subsection{WARRANTS OF FITNESS}

In the absence of legal compulsion to retrofit buildings or other property, the concept of a warrant of fitness with a range of grades of fitness has some merit. The range of grades proposed by the NZSEE (2000), A, B, and C which pass the test, and D and E which don't, would become public knowledge as they would be displayed at the entrance to each building. This would allow prospective tenants, employees, or others who might enter the building, or prospective buyers of the building, to decide what level of risk they are prepared to accept, and puts pressure on the owner to retrofit the building if it is grade $\mathrm{D}$ or $\mathrm{E}$

A related problem is that of risk-enhancing changes that are made to a structure after its initial construction. For example cutting large holes in structural walls, or filling in movement gaps on seismically isolated structures (Item B13). Periodic (quinquennial, say) reviews of the warrant of fitness would capture such problems, but is the compliance cost-justified?

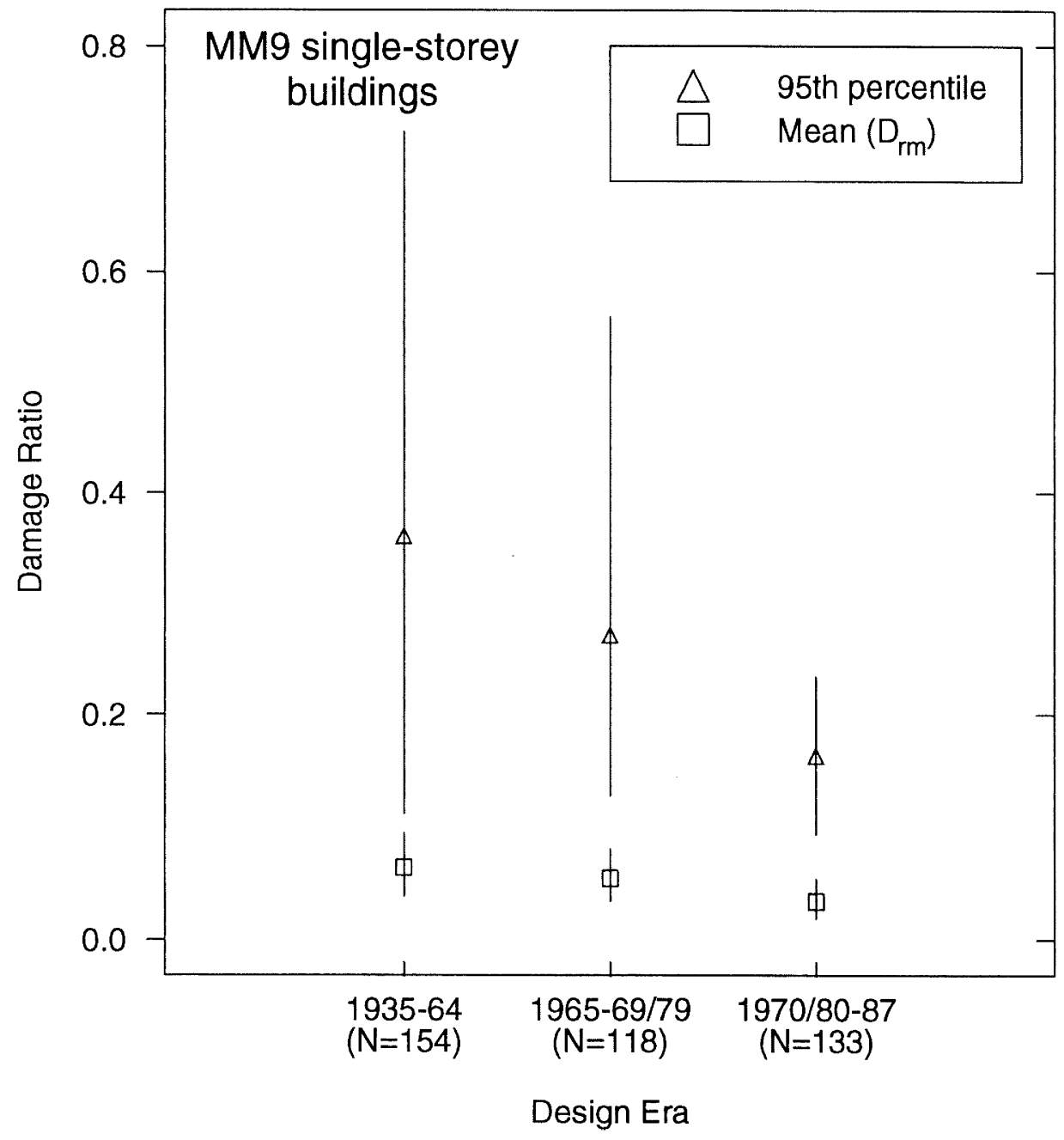

Figure 5: Mean and $95^{\text {th }}$ percentile of damage ratio for non-domestic buildings in the intensity MM9 zone of the 1987 Edgecumbe earthquake. The uncertainty limits are the $2.5 \%$ and $97.5 \%$ quantiles of the distributions.

\subsection{CONCLUSIONS}

1. Over twenty weaknesses are identified in New Zealand's systems for earthquake risk reduction, some of which are matters of broad policy and others very specific. Perhaps the most fundamental is to develop and operate a national strategy for earthquake risk reduction with time.

2. Actions required to remedy the weaknesses involve more than 11 parties, ranging from earthquake professions to government and property owners. A preliminary check list of who should do what has been presented. Such a checklist should be circulated to all parties involved.

3. Earthquake professions are found to have advocacy roles in addressing all 26 weaknesses. Professional engineers have engineering technical actions in addressing 70 percent (20) of the weaknesses. 
4. The complexity of the processes of remedying the weaknesses is shown by the fact that 15 of the weaknesses could have remedial actions from five or more parties.

5. The concept of a periodic Warrant of Fitness for a structure or other property appears to have considerable potential for dealing with existing property, and with changes which reduce earthquake performance, e.g. cutting holes in structural walls, or poor maintenance.

6. Duty of Care for the public gives all parties more responsibility for remedial action than many people may realise.
7. The potential exists for reducing financial losses in future earthquakes by about an order of magnitude, i.e. billions of dollars and thousands of casualties if the whole of the built environment were to be converted to the lower bound of earthquake vulnerability.

8. New Zealand has many strengths (16 listed here) which provide a good framework for addressing the huge task of earthquake risk reduction.

9. We engineers should lead the development of a national plan for earthquake risk reduction in New Zealand.

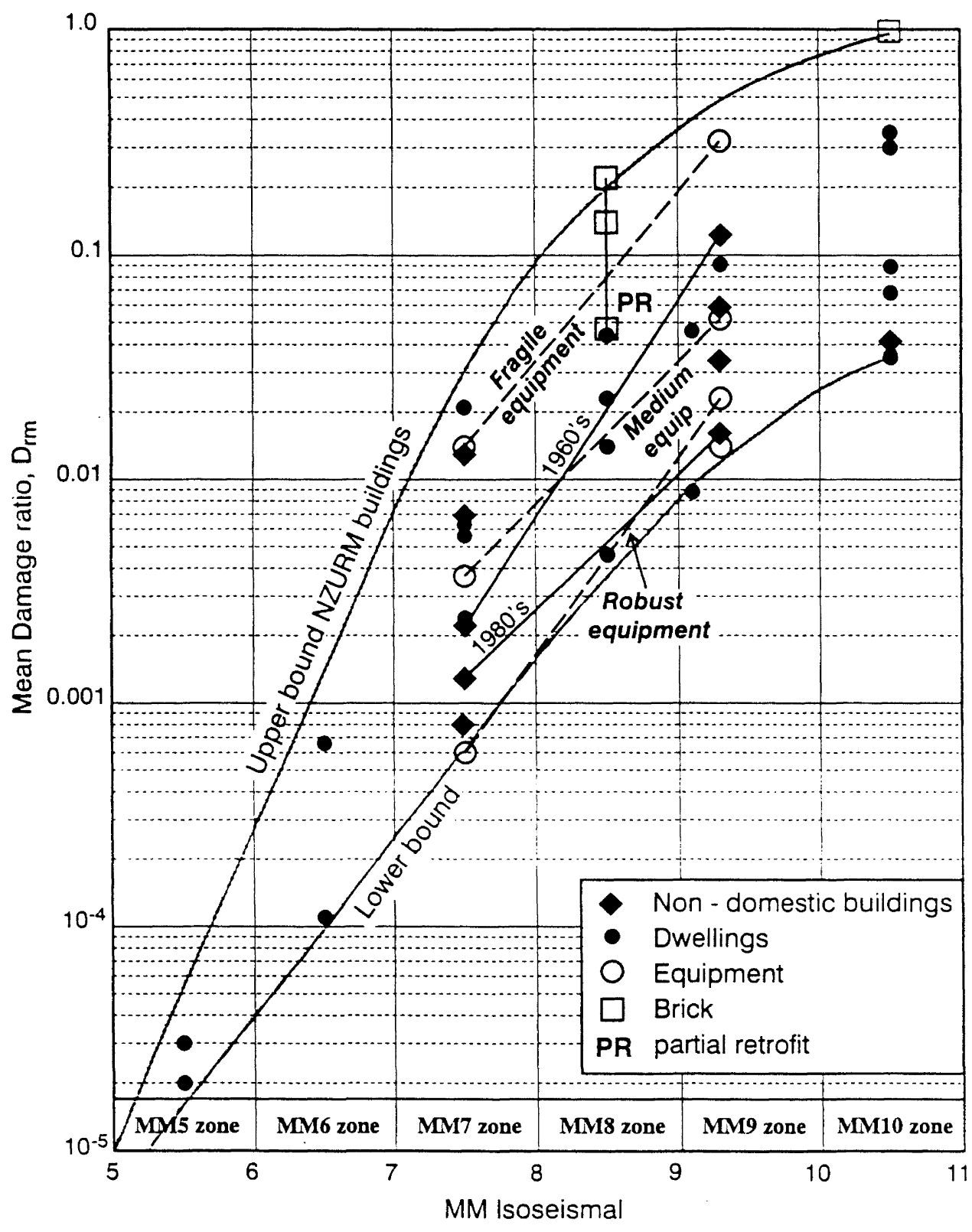

Figure 6: Mean damage ratio data from New Zealand earthquakes for buildings and equipment as a function of intensity, with approximate upper and lower bounds (from Dowrick, 2003). 


\section{ACKNOWLEDGEMENTS}

This paper was funded by FRST under Contract No CO5X0006. The author thanks Hyland Marshall, Emergency Management Advisor of Porirua City Council for help in developing Tables 2(a) and 2(b). Thanks are due to $P$. Davenport, J. Cousins and G. Hancox for their in-house reviews of the manuscript, and also to an anonymous reviewer.

\section{REFERENCES}

Beattie, G.J. (2000), The design of building services for earthquake resistance. Paper No. 2462, Proc $12^{\text {th }}$ World Conf on Earthq Eng, Auckland (CD Rom).

Dowrick, D.J. (2003), Earthquake risk reduction. John Wiley \& Sons, Chichester.

Dowrick D.J. and Rhoades D.A. (1997), Inferences for design, insurance and planning from damage evaluation in past New Zealand earthquakes. Journal of Earthquake Engineering, 1(1): 77-91.

Dowrick D.J., Rhoades D.A. and Davenport P.N. (2001), Damage ratios for domestic property in the magnitude 7.21968 Inangahua, New Zealand, earthquake. Bull NZ Soc for Earthq Eng, 34(3): 191-213.

Dowrick, D.J., Rhoades, D.A. and Davenport, P.N. (2003), Effects of microzoning and foundations for domestic property in the magnitude 7.2 Inangahua, New Zealand, earthquake of 1968. Bull NZ Soc for Earthq Eng, 36(1): 25-46.

Dowrick, D.J., Rhoades, D.A., Babor, J. and Beetham, R.D. (1995), Damage ratios and microzoning effects for houses in Napier at the centre of the magnitude 7.8 Hawke's Bay, New Zealand, earthquake of 1931. Bull NZ Nat Soc for Earthq Eng, 28(2): 134-45.

EERI (2002), Arresting the growth of earthquake vulnerability: Needs and opportunities for earthquake engineering. Draft Plan for Review by EERI membership. Earthquake Engineering Research Institute, California.

Hopkins, D.C. (2002), NZSEE Earthquake Risk Buildings Study Group. Technical Conf NZ Soc for Earthq Eng, Napier, Paper 5.6.

IPENZ (2003), Report of the structural taskforce enquiring into the state of structural engineering in New Zealand.
The Institution of Professional Engineers New Zealand Inc.

King, A., Brunsdon D., Shephard, B., Kerr, J. and Van Dissen, R. (2003), Building adjacent to active faults: a risk-based approach. Proc. $7^{\text {th }}$ Pacific Conf on Earthq Eng., Christchurch (CD Rom, Paper 158).

Mander, J.B. (2001), Future directions in seismic design and performance-based engineering. Technical Conference of the NZ Society for Earthquake Engineering, Wairakei, Paper 2.01.

NZSEE Study Group (2000), An initial evaluation process for identifying buildings not safe in earthquake. Recommendations of the NZSEE Study Group on Earthquake Risk Buildings, prepared for the Building Industry Authority, Draft 8.

NZNSEE Study Group (1996), The assessment and improvement of the structural performance of earthquake risk buildings. NZ Nat Soc for Earthq Eng. Draft for General Release, prepared for the Building Industry Authority.

NZS 4219 (1983), Specification for seismic resistance of engineering systems in buildings. Standards Association of New Zealand, Wellington.

Scarry, J. (2002), An open letter to IPENZ regarding the parlous state of the structural engineering profession and the construction industry in New Zealand. John Scarry (December), $141 \mathrm{pp}$.

Shipp, J.G. and Johnson, M.W. (1990), Seismic loss estimation for non-structural components in high-rise buildings. Proc $4^{\text {th }}$ US Nat Conf on Earthq Eng, EERI, Oakland, California.

Smith, W. (2003), Criteria for strengthening buildings: costbenefit analysis is misleading. Bull NZ Soc for Earthq Eng., 36 (4), 260-262 (this issue).

Spence, R.J.S., Pomonis, A., Dowrick, D.J. and Cousins, W.J. (1998), Estimating human casualties in earthquakes: The case of Wellington. In Seismic Design Practice into the Next Century, Booth (ed), Balkema, Rotterdam, 277 86.

Van Dissen, R. and 13 others (2003), An interim classification of New Zealand's active faults for the mitigation of surface rupture hazard. Proc $7^{\text {th }}$ Pacific Conf on Earthq Eng, Christchurch (CD Rom, Paper 155). 